\title{
SCHOOL AS A "PROTECTIVE FACTOR" AGAINST DRUGS: PERCEPTIONS OF ADOLESCENTS AND TEACHERS
}

\author{
María del Carmen García de Jesús ${ }^{1}$ \\ Maria das Graças Carvalho Ferriani ${ }^{2}$
}

García de Jesús MC; Ferriani MGC. School as a "protective factor" against drugs: perceptions of adolescents and teachers. Rev Latino-am Enfermagem 2008 maio-junho; 16(especial):590-4

This study aims to discover and describe protective factors regarding the use of drugs, according to teachers and students, aged 14 to 15 years, from a Public Secondary School in Santiago de Querétaro, Mexico. This is a descriptive and exploratory study. Data collection was carried out through semi-structure interview and non-participative observation with ten students and five teachers. Three themes resulted from data analysis: school and school's environment: the school does not provide a healthy environment; use of drugs: perceived by both the students and teachers in the institution itself; prevention programs: there are health promotion and prevention programs available at the school. According to the students' and teachers' perceptions, the school represents a risk factor.

DESCRIPTORS: education, primary and secondary; schools; adolescents

\section{LA ESCUELA COMO "FACTOR PROTECTOR" PARA LAS DROGAS: UNA VISIÓN DE ADOLESCENTES Y MAESTROS}

El presente trabajo tuvo como objetivo conocer y describir los factores protectores en relación con el consumo de drogas, que son considerados por los profesores y alumnos entre 14 y 15 años de edad, de una escuela pública de la ciudad de Santiago de Querétaro, México. Este estudio descriptivo y exploratorio utilizó entrevistas semi-estructuradas y observación no participativa, las cuales fueron aplicadas a 10 alumnos y 5 profesores. Del análisis de los datos surgen tres temáticas: escuela y ambiente escolar: la escuela no favorece un ambiente escolar saludable; consumo de drogas: se observa que tanto los alumnos y maestros consumen drogas en la institución; programas de prevención: la escuela tiene programas de prevención y promoción a la salud, pero no alcanzan a todos los alumnos. Los resultados refieren que la escuela es un factor de riesgo según la visión de profesores y alumnos.

DESCRIPTORES: educación primaria y secundaria; instituciones académicas; adolescentes

\section{A ESCOLA COMO "FATOR DE PROTEÇÃO" PARA DROGAS: UMA VISÃO DOS ADOLESCENTES E PROFESSORES}

O objetivo deste trabalho foi conhecer e descrever os fatores de proteção em relação ao consumo de drogas, considerado por professores e adolescentes, entre 14 e 15 anos de idade, de uma Escola Pública Secundária na cidade de Santiago de Querétaro, México. Este estudo descritivo e exploratório utilizou entrevista semi-estruturada e a observação não participativa na coleta de dados. Os sujeitos do estudo foram dez alunos, ambos os sexos, e cinco professores do sexo feminino. Os resultados foram agrupados em três temas: escola e ambiente escolar: interpretado como a escola não favorece um ambiente saudável; consumo de drogas: é percebido tanto por alunos como professores na própria instituição; programas de prevenção: a escola possui programa de prevenção, entretanto, o mesmo não atinge a todos os alunos. Na visão dos adolescentes e professores, a escola não se apresenta como Fator de Proteção, mas sim como Fator de Risco.

DESCRITORES: educação primária e secundária; instituições acadêmicas; adolescentes

\footnotetext{
${ }^{1}$ Faculty, Autonomous University of Querétaro, College of Nursing, Mexico, e-mail: nemac@uaq.mx; ${ }^{2}$ Full Professor, University of São Paulo at Ribeirão Preto, College of Nursing, WHO Collaborating Centre for Nursing Research Development, Brazil, e-mail: caroline@eerp.usp.br
} 


\section{INTRODUCTION}

The drug phenomenon represents one of the biggest public health problems in Mexico today. Teenagers are involved, as the results of the National Addictions Research show: more than 200,000 teenagers between 12 and 17 years old (215.634) use drugs. In terms of gender, for every female user, there are 3.5 male users., On the average, consumption started at the age of 14 . These statistics show that drugs use as one of the most problematic behaviors in young people nowadays and is more frequent in the teenage population ${ }^{(1)}$.

Adolescence is a transition phase between childhood and adult age, which is characterized by the group of physical, psychological, emotional and social changes, together with internal and external physical development. Modifications occur in the social structure, with an increasing importance of the friends group. Furthermore, adolescents tend to imitate the group's way of dressing, speaking and acting, adopting habits that negatively affect their health ${ }^{(2)}$. These actions can condition teenagers to use alcohol and other drugs. These experiences can provoke their denial or acceptance of these kinds of substances, which generates significant problems for individual and family health ${ }^{(3)}$.

In view of this situation, it is important for educational institutions to support the promotion and strengthening of "protection factors" to avoid drugs use. These allow people to face the problems they are confronted with and open an array of possibilities, emphasizing the positive forces or aspects of human beings.

The school is a propitious environment for students to develop a healthy way of living, involving cognitive, emotive, affective, cultural, behavioral, and social patterns. This helps teenagers to resist drugs use, lowering that risk ${ }^{(4)}$. This way, the school has a vital role as a protection factor in the psychosocial development of children and teenagers ${ }^{(5)}$. The promotion of School Education Programs is important, since it is a place where students become aware of the skills for life and the school becomes a protection factor that favors the ideal physical, social, and psychological well-being. Their purpose is to provide the future generations with knowledge, abilities, and skills to promote and care for their health, and create and maintain a healthy study, work and cohabitation environment ${ }^{(6)}$. In order to become a protection factor against drug use, the school should create support networks with parents, students and teachers so as to strengthen the students' healthy habits. School health promotion should be based on the following principles: articulation between the health and education sectors to establish work programs; construction of an interdisciplinary and multidisciplinary perspective; comprehension of the reality; and development of student, family, and teacher groups ${ }^{(7)}$. On that account, it is fundamental to implement health policies in public schools, to perform health promotion inside the institutions. These, in turn, will be instructed about the addictions problems in the school population and can therefore support and promote the protection factors against drugs.

\section{OBJECTIVES}

To learn and describe the protection factors related to drugs use, considered by teachers and 1415-year-old teenagers of a secondary public school in the city of Santiago de Querétaro, Mexico.

The specific objectives were:

- To identify if the teenagers of 14-15 years old can perceive what protection factors the school offers against drugs use;

- To identify if the teacher can perceive what protection factors the school offers to 14-15 year-olds against drugs use;

- To identify if the school supports the protection factors against drugs use present in teenagers.

\section{METHODOLOGY}

This is a descriptive and exploratory study, performed at a secondary public school in Santiago do Querétaro, Mexico, with the participation of ten students and five teachers.

This study considered the ethical aspects established in the determinations and general principles of the Mexicans Health Law related to health research. The following will be used: Second Title 
Chapter I, articles 13, 14, 16, 17, 18, 20, 21, 22, as well as Chapter V, article 57.

The research in question does not represent any kind of risk to society, since it does not manipulate the teenage population

To continue with the research, an authorization request to perform the study was sent to the secondary public school's principal. The individuals who participated in the investigation provided written consent that stated the purpose of the research, as well as the result treatment, which would be informed to the teenagers, parents and teachers.

The sample was distributed at random, using a list. This study used the techniques of non-participant observation and semi-structured interview. Data was recorded through brief and detailed notes, recordings, and observation records, among others. Inside the data collection plan, the qualitative researcher uses a reflexive posture and tries to eliminate, as much as possible, the beliefs or experiences associated to the studied theme, to avoid any influence on the results ${ }^{(8)}$. Data collection was performed in the classroom and in the institution's public spaces, with a view to obtaining additional data to reach the previously established objectives. The data analysis had three purposes: 1) To comprehend the collected data, 2) to confirm the research premises and/or answer the research question, and 3 ) to increase knowledge about the investigated project, linking it with the cultural context ${ }^{(9)}$. Data analysis was performed through semistructured interviews and non-participant observation. The content concepts were grouped in categories, seeking to join common features.

\section{RESULTS AND DISCUSSION}

\section{Individual Characteristics}

The study participants were ten students, six males and four females, between 14 and 15 years old, who attended school in the evening. The five teachers who participated were women between 29 and 50 years old, with career time between 5 and 29 years. They taught diverse subjects, like mathematics, social works, physical education and guidance. Most of them had two jobs.
The results were grouped in three themes: school and school environment, drugs use, and prevention programs

- School and School Environment

The teachers state that the secondary school does not support or favor a healthy school environment. The students point out that the teachers do not give examples of their acts and that there is a lack of adequate guidance.

In view of this situation, it is important for teenagers to be able to count on people that provide them with confidence and guidance. This situation favors the consolidation of a healthy lifestyle, where parents and teachers have a fundamental role, and where the school must prioritize the promotion and education of teenagers' health, thus improving their quality of life. As previously stated, the school is a propitious environment for students to acquire abilities and skills that can favor their own, their family's and social health.

- Drugs Use

Concerning drugs use, the teachers admit that they smoke at the facilities and some have even come to work smelling alcohol. They also mention that some students smoke too, and occasionally consume alcohol inside the school facilities. In turn, the students state that the teachers smoke inside classrooms and do not live by the example they verbally propose, since some of them offer guidance to students regarding drugs use. Similarly, the youngsters state that some of their companions smoke at the back of the school and do not care if they are suspended or expelled. The reasons they give for using psychoactive substances are defiance, liking it, lack of understanding from their families, and belonging to a friends group, among others.

Drugs use among students is associated with disapproval, family disintegration or low self-esteem. This phenomenon is observed more frequently in teenagers, a vulnerable population where the family, friends, society and communication influence drugs use. This fact causes a serious problem since, as previously mentioned, adolescence is a vulnerable stage, when the young people facepersonal, family and social changes. Therefore, this stage is crucial not only for the teenagers, but also for their family, 
friends, and teachers, who must know how to deal with the conflicts the teenagers suffer.

Thus, prevention should focus on strengthening and promoting protection factors in the school environment, giving children and youngsters the options to decide for a healthier lifestyle ${ }^{(6)}$.

- Prevention Programs

Regarding prevention programs, some teachers report that the school offers guidance, support, motivation, confidence and talks that favor a healthy lifestyle for teenagers. However, these efforts are affected by the bad examples some teachers give to the students. Besides, the lectures that occur in the institution occur in the morning, or occasionally according to a specific schedule. The students insinuate that the school offers training, teaching and advice to keep them away from drugs, but unfortunately this occurs only in the morning, and that, whenever it does occur in the evening, it is directed to some specific groups.

In view of this problem, educational institutions need to implement strategies that allow the teenagers to become aware of the serious problem drugs use represents. It is important for school principals to link up with other institutions to provide a culture of health promotion and drug prevention, which should take place in class hours. Schools should support health promotion programs, besides counting on an articulation between the health and education sectors to establish work programs; build an interdisciplinary and multi-disciplinary perspective; understand the reality; and foster the development of student, family, and teacher groups ${ }^{(7)}$.

During non-participant observation, it was noticed that the school environment is not appropriate for teenagers, because it is located in a conflict zone of the city. Therefore, the students are influenced by the youngsters on the streets. Besides, it was observed that, in the school, students show great apathy towards the institution, generating great disinterest in keeping the installations in good conditions or in a healthy environment. It was also observed that there is a loss of values, because the students do not respect the teachers and companions. In turn, most teachers do not show interest in the students' academic and personal development. Often, they do not care for the students' problems, and this makes students consider themselves unimportant.

\section{CONCLUSIONS}

According to the objectives, it was observed that the teachers and students do not identify the school as a "protection factor". That confirmation was based on the results obtained through interviews and non-participant observation, where it was analyzed that the school is not appropriate to generate a healthy environment for teenagers.

Hence, the students state that the teachers do not put what they say in practice, because they are the first to smoke inside the institution. Besides, they mention that some teachers come to school with their breath smelling of alcohol, and said that the school is not a protection factor, according to the interviews performed in the "Secondary School". Both students and teachers report that the school is a space that propitiates the abuse of substances that cause dependence, because the students follow the example of their teachers and companions.

In the same way, the teachers mention the the institution authorities' need for an adequate program to foment a healthy environment and the teenager's integral development.

Therefore, the current study considers it important to highlight that the "School", in the teenagers and teachers' point of view, is not a "protection factor", but rather a risk factor. To reverse this aspect, it is important for teachers and students to become aware of the importance of establishing health promotion and drug prevention programs in order to prevent drugs use. The Public Education Secretary and the school rector need to become aware of the importance of generating health policies that contribute to a healthy environment for students, achieved through health education programs. These policies must address health promotion and drugs prevention, considering the extent of the teenage drug dependence phenomenon in Querétaro, according to the 2002 National Addictions Research.

Health promotion is fundamental in students' development. An articulation between the education and health sectors must exist to support school health, especially in secondary schools, where teenagers adopt or imitate adult actions without concern with the damage these acts can cause, or to belong to a particular group $^{(7)}$

Secondary schools should also articulate with the University, with active participation of the Nursing 
School to develop prevention programs for teenagers and make them aware of the problems and their consequences. This joint work will allow teenagers and teachers to change their views, turning the school into a "protection factor" against drugs use.

\section{ACKNOWLEDGEMENTS}

Acknowledgements to the Inter-American Drug Abuse Control Commission/CICAD of the SubSecretary of Multidimensional Security at the
Organization of American States/OAS, the Brazilian Anti-Drugs Secretary/SENAD, faculty members at the University of São Paulo at Ribeirão Preto College of Nursing, WHO Collaborating Centre for Nursing Research Development, Brazil, to the population who participated in the studies and to the representatives from eight Latin-American countries who participated in the I and II On-Line Specialization Program for Research Capacity-Building on the Drugs Phenomenon-PREINVEST, offered in 2005/2006 by the University of São Paulo at Ribeirão Preto College of Nursing, as a distance education course.

\section{REFERENCES}

1. Secretaría de Salud (SSA). Encuesta Nacional de Adicciones: alcohol, tabaco y drogas. Disponible en: www.ssa.gob.mx. México; 2002.

2. Zagury T. O adolescente por ele mismo 11ed. Rio de Janeiro: Editorial Record; 2001.

3. Beck FK. Diagnoctic and Statistical Manual of Mental Disorders (DSM-III-R). Washigton: American Psychiatric Association; 1987.

4. Secretaria de Educación Pública, SEP, México. Programa Interinstitucional de Educación Saludable: Escuela saludable y segura, libre de humo de tabaco. 2001. Disponible en: http:/ /www.sep.gob.mx/wb2/sep/sep_Bol4441104

5. Consejo Nacional para el Control de Estupefacientes (CONACE); Programa de Prevención de Adicciones en Chile. 2004. Disponible en: http://www.conace.cl/inicio/conace.php. 6. Organización Panamericana de la Salud (OPS). Escuelas Promotoras de Salud en las Américas (2005). Disponible en: http://www.paho.org/spanish/HPP/HPM/HEC/hs_about.htm. 7. Ferriani MGC. Saúde Escolar: Contradições e desafios. Goiânia: AB Editora; 2005.

8. Minayo MCS. Pesquisa Social: Teoría, método e criatividade. 23 ed. Petrópolis: Editora Vozes; 1994.

9. Minayo MC. Fase de trabalho de campo. In: Minayo MCS:

O desafio do conhecimento: pesquisa qualitativa em saúde.

São Paulo: HUCITEC-ABRAS-CO; 1992. p. 105-96. 